\title{
Kształtowanie się ustroju kolegiów orzekających w Polsce Ludowej (1952-1956)
}

I. Struktura kolegiów orzekających. Przeprowadzona w grudniu $1951 \mathrm{r}$. reforma orzecznictwa karno-administracyjnego Polski Ludowej zmieniła w sposób zasadniczy ustrój organów orzekających. Sięgający korzeniami okresu międzywojennego dotychczasowy model orzecznictwa ${ }^{1}$, w którym sprawy o wykroczenia rozstrzygali referenci karno-administracyjni, uznano za anachroniczny ,z punktu widzenia prawidłowego rozwoju państwa budującego ustrój socjalistyczny"2. Jednoosobowe orzecznictwo wykonywane przez czynnik urzędniczy zastapiono kolegialnym sposobem orzekania z udziałem aktywu społecznego, co miało stanowić wyraz „praktycznej realizacji zasady przyciągania mas do bezpośredniego udziału w zarządzaniu państwem"3. Koncepcja uspołecznienia i demokratyzacji orzecznictwa w sprawach o wykroczenia legła u podstaw uchwalonej w dniu 15 grudnia $1951 \mathrm{r}$. ustawy o orzecznictwie karno-administracyjnym ${ }^{4}$ (ustawa z 15 grudnia 1951 r.), która powołała do życia kolegia przy prezydiach rad narodowych wszystkich szcze$\mathrm{bli}^{5}$. Kolegia utworzono przy prezydiach gminnych, miejskich, dzielnicowych, powiatowych i wojewódzkich rad narodowych. Na równi z kolegiami szczebla wojewódzkiego traktowano kolegia przy prezydiach największych miast posiadających status administracyjny województwa - Warszawie i Łodzi. Ko-

${ }^{1}$ Wprowadzony rozporządzeniem Prezydenta RP z 22 marca 1928 r. o postępowaniu karno-administracyjnym (Dz. U. nr 75, poz. 444).

${ }^{2}$ J. Skupiński, Model polskiego prawa o wykroczeniach, Warszawa 1974, s. 113.

${ }^{3}$ Notatka w sprawie wyborów do kolegiów karno-administracyjnych działających przy prezydiach rad narodowych, Instytut Pamięci Narodowej w Warszawie, Biuro Udostępniania i Archiwizacji Dokumentów, zespół akt Ministerstwo Spraw Wewnętrznych II, sygn. teczki 16162, s. 41 (IPN BU MSW II 16162, s. 41).

${ }^{4}$ Dz. U. Nr 66, poz. 454.

${ }^{5}$ Kolegia nie miały początkowo specjalnej nazwy dopiero w 1958 r. ustawodawca wprowadził określenie kolegia karno-administracyjne. Do tego czasu w języku potocznym określane były mianem kolegiów orzekających, nazwa ta została użyta w ustawie z 25 września 1954 r. o reformie podziatu administracyjnego wsi i powołaniu gromadzkich rad narodowych (Dz. U. nr 43, poz. 191) 
legia szczebla wojewódzkiego były organem II instancji o charakterze wyłącznie odwoławczym i zostały utworzone w związku z wprowadzeniem odwołania do kolegium wyższej instancji w miejsce żądania skierowania sprawy na drogę postępowania sądowego. Kluczową rolę w systemie kolegiów odgrywały kolegia przy prezydiach powiatowych, dzielnicowych oraz rad narodowych większych miast. Stanowiły one organy I instancji i dysponowały pełnią uprawnień w zakresie orzekania kar przewidzianych ustawą z 15 grudnia 1951 r. Były również instancją odwoławczą od orzeczeń kolegiów działających przy prezydiach gminnych rad narodowych, które dysponowały ograniczonymi kompetencjami do wymierzania kar. Kolegia szczebla gminnego mogły orzec karę grzywny w granicach do 300 złotych i karę pracy poprawczej w wymiarze do 6 dni, podczas gdy maksymalna wysokość tych kar przewidziana w ustawie z 15 grudnia 1951 r. wynosiła w przypadku grzywny 3000 złotych, a pracy poprawczej 3 miesiące ${ }^{6}$. Stanowiąca wyraz wychowawczej koncepcji orzecznictwa karno-administracyjnego kara pracy poprawczej była wykonywana poprzez potrącenie $20 \%$ wynagrodzenia osoby ukaranej bez odrywania jej od dotychczasowego miejsca pracy. Ponadto ustawa z 15 grudnia 1951 r. przewidywała stosowane w przypadku małej szkodliwości społecznej czynu upomnienie, które miało postać środka potępienia moralnego sprawcy wykroczenia ${ }^{7}$.

Przyznanie kolegiom przy prezydiach gminnych rad narodowych skromnych kompetencji w zakresie orzekania środków karnych należy odczytać jako wyraz ograniczonego zaufania ustawodawcy do idei wprowadzenia orzecznictwa karno-administracyjnego na najniższym szczeblu podziału terytorialnego kraju. Rozwiązanie to traktowano przede wszystkim w kategoriach propagandowych jako wyraz ,zbliżenia organów władzy ludowej do obywatela”, gdyż dotychczas orzecznictwo karno-administracyjne było sprawowane na szczeblu powiatu i w miastach stanowiących powiaty miejskie. Utworzenie kolegiów w gminach i mniejszych miastach miało umożliwić „ściślejsze powiązanie organów orzekających z potrzebami terenu" ${ }^{8}$, a także realizację wychowawczej funkcji orzecznictwa karno-administracyjnego poprzez ,lepsze zbadanie całokształtu sprawy wskutek znajomości warunków miejscowych, otoczenia sprawcy i okoliczności czynu"9. Dokonana w 1954 r. reforma podziału administracyjnego wsi polegająca na utworzeniu gromad w miejsce gmin, skutkowała likwidacja gminnych rad narodowych i przekazaniem ich zadań gromadzkim radom narodowym. Dotychczasowe kompetencje prezydiów gminnych rad narodowych w zakresie orzecznictwa karno-administracyjnego przeszły na pre-

\footnotetext{
${ }^{6}$ K. Siarkiewicz, Ksztaltowanie się ustroju kolegiów, „Zagadnienia Wykroczeń” 1977, nr 4-5, s. 36.

${ }^{7}$ R. Rajkowski, Prawo karno-administracyjne Polski Ludowej, Warszawa 1955, s. 82.

${ }^{8}$ O pracy kolegiów orzekajacych w postępowaniu karno-administracyjnym, Warszawa 1952, s. 7.

${ }^{9}$ E. Dornfest, $W$ jaki sposób będziemy realizowali ustawę o orzecznictwie karno-administracyjnym, „Rada Narodowa” 1952, nr 1, s. 21.
} 
zydia gromadzkich rad narodowych, co wymagało utworzenia organów rozpatrujących w gromadach sprawy o wykroczenia. Przygotowując reformę najniższego szczebla podziału terytorialnego kraju sprawujące w imieniu Prezesa Rady Ministrów zwierzchni nadzór nad orzecznictwem karno-administracyjnym Biuro Społeczno-administracyjne Zespołu II Prezydium Rady Ministrów ${ }^{10}$ wystąpiło z propozycją przekazania kompetencji kolegiów gminnych prezydiom gromadzkich rad narodowych, które w myśl zasady kolegialności miałyby orzekać w składzie 3-osobowym ${ }^{11}$. Ostatecznie pomysł rezygnacji z tworzenia kolegiów gromadzkich nie wszedł w życie, gdyż zgodnie ze stanowiskiem Wydziału Prawnego Rady Ministrów uznano „za najwłaściwsze utrzymanie jednolitego systemu na wszystkich szczeblach i utworzenie w gromadach kolegiów orzekających" 12 .

Kolegia gminne przestały funkcjonować w listopadzie 1954 r., zaś kolegia gromadzkie przystapiły do pracy dopiero w drugim kwartale $1955 \mathrm{r}$. Było to spowodowane zaangażowaniem prezydiów rad narodowych w ,akcję przygotowawczą do wyborów do Rad Narodowych", czyli w organizacje pierwszych w powojennej Polsce wyborów do rad narodowych. Obsługujące kolegia oddziały społeczno-administracyjne prezydiów powiatowych rad narodowych nie były w stanie poświęcić należytej uwagi szkoleniu i instruktażowi członków kolegiów gromadzkich. Szczególnie obciążeni pracami związanymi z przygotowaniem wyborów do rad narodowych byli kierownicy oddziałów społeczno-administracyjnych, stąd „kolegia w większości przypadków pozbawione były właściwej opieki, kierownictwa i instruktażu"13.

Jedynie w tych gromadach, gdzie w skład kolegiów powołano osoby zasiadające w byłych kolegiach gminnych udało się uruchomić orzecznictwo jeszcze w pierwszym kwartale 1955 r. Przesunięcie pracowników oddziałów społeczno-administracyjnych do prac związanych z wyborami rad narodowych i organizowaniem od podstaw rad szczebla gromadzkiego wynikało $\mathrm{z}$ niedostatecznej obsady personalnej aparatu biurokratycznego powiatowych rad narodowych. Konsekwencją takiego stanu rzeczy była ponadczteromiesięczna przerwa w funkcjonowaniu orzecznictwa karno-administracyjnego na najniższym szczeblu podziału terytorialnego kraju, stąd „w tym

${ }^{10}$ Początkowo zwierzchni nadzór nad orzecznictwem karno-administracyjnym sprawował Prezes Rady Ministrów. Po reaktywowaniu Ministerstwa Spraw Wewnętrznych na początku 1955 r. kompetencje w tym zakresie przeszły na Ministra Spraw Wewnętrznych.

${ }^{11}$ Pismo dyrektora Biura Społeczno-Administracyjnego Zespołu II Prezydium Rady Ministrów M. Broniatowskiego w sprawie uzupełnienia projektu ustawy o gromadzkich radach narodowych, IPN BU MSW I 6624, s. 91.

${ }^{12}$ Notatka w sprawie stanowiska Biura Organizacyjnego odnośnie [do]organizacji orzecznictwa k.a. na szczeblu gromadzkim, IPN BU MSW I 6624, s. 93.

${ }^{13}$ Sprawozdanie Prezydium Wojewódzkiej Rady Narodowej w Warszawie z ruchu spraw karno-administracyjnych za IV kwartał 1954 r., IPN BU MSW I 526, s. 307. 
właśnie okresie przejściowym dość duża ilość spraw uległa przedawnieniu orzekania"14.

W wyniku reformy podziału administracyjnego wsi liczba kolegiów wzrosła niemalże trzykrotnie, gdyż w miejsce dotychczasowych 3000 gmin powołano do życia 8800 nowych gromad. Stosunkowo niewielkie w porównaniu z gminami gromady cechowała słabość gospodarcza i organizacyjna, co przełożyło się na niski poziom funkcjonowania prezydiów gromadzkich rad narodowych, odczuwających dotkliwie braki fachowej kadry urzędniczej. Problemy organizacyjne związane z przejęciem przez prezydia gromadzkich rad narodowych zadań wykonywanych dotychczas na szczeblu gminnym stawiały pod znakiem zapytania zasadność tworzenia kolegiów orzekających w tak małych jednostkach podziału terytorialnego. Władze zdawały się nie dostrzegać tych zagrożeń, wręcz przeciwnie, wyrażały przekonanie że kolegia gromadzkie ,powinny [...] lepiej pracować niż dawniejsze kolegia gminne, ponieważ są bliższe ludności i mogą w swej pracy korzystać z doświadczeń kolegiów gminnych"15.

Podobnie jak kolegia szczebla gminnego, także kolegia przy prezydiach gromadzkich rad narodowych miały ograniczone kompetencje w zakresie stosowania środków karnych przewidzianych ustawą z 15 grudnia $1951 \mathrm{r}$. W razie stwierdzenia, że sprawca wykroczenia zasługuje na wyższą niż karę niż 6 dni pracy poprawczej lub 300 złotych grzywny przekazywały sprawę kolegium szczebla powiatowego ${ }^{16}$.

II. Pozycja kolegiów w systemie rad narodowych. Nawiązując „do założeń ustrojowych państwa socjalistycznego", ustawa z 15 grudnia $1951 \mathrm{r}$. włączyła orzecznictwo karno-administracyjne do systemu organizacyjnego rad narodowych. Rozwiązanie to miało na celu zagwarantowanie bezpośredniego wpływu organów przedstawicielskich, jakimi oficjalnie były rady narodowe, na politykę karną w sprawach o wykroczenia. Orzecznictwo karno-administracyjne traktowano bowiem w kategoriach narzędzia wspierającego rady narodowe $\mathrm{w}$ realizacji ich zadań państwowych oraz $\mathrm{w}$ zapewnieniu porządku społecznego na terenie ich działania ${ }^{17}$.

Działalność kolegiów miała służyć urzeczywistnieniu konstytucyjnych zadań rad narodowych w zakresie utrzymania porządku publicznego ${ }^{18}$, lecz roz-

\footnotetext{
${ }^{14}$ Sprawozdanie Prezydium Wojewódzkiej Rady Narodowej w Zielonej Górze z przebiegu orzecznictwa karno-administracyjnego w I kwartale 1955 r., IPN BU MSW I 526, s. 402.

${ }^{15}$ Pismo Biura Nadzoru nad Orzecznictwem Karno-Administracyjnym MSW dotyczące wyborów do kolegiów k.a. przy prezydiach gromadzkich rad narodowych, IPN BU MSW I 523, s. 2.

${ }^{16}$ M. Jaroszyński, M. Zimmermann, W. Brzeziński, Polskie prawo administracyjne, Warszawa 1955, s. 423.

${ }^{17}$ M. Siewierski, Prawo o wykroczeniach jako narzędzie realizacji zadań administracji, „Zagadnienia Wykroczeń” 1977, nr 4 -5, s. 49.

${ }^{18}$ R. Rajkowski, op. cit., s. 127.
} 
wiązania ustawy z 15 grudnia 1951 r. poszły w kierunku powiązania kolegiów z prezydiami rad narodowych. Prezydia rad narodowych sprawowały funkcję organów wykonawczych i zarządzających rad narodowych oraz terenowych organów administracji państwowej. Funkcję jednoosobowych organów administracji pełnili przewodniczący prezydium, zaś nieposiadające własnej kompetencji wydziały prezydium zarządzały sprawami należącymi do właściwości rad narodowych. Wbrew intencjom ustawodawcy, który pochodzącym z wyborów radom narodowym nadał rangę organów jednolitej władzy państwowej w poszczególnych jednostkach podziału terytorialnego, prezydia zdominowały rady narodowe, przejmując większość ich funkcji ${ }^{19}$. Dotyczyło to także spraw karno-administracyjnych, należących zgodnie z ustawą o terenowych organach jednolitej władzy państwowej z 20 marca $1950 \mathrm{r}^{20}$ do zakresu działania rad narodowych.

Prezydia rad narodowych kierowały działalnością kolegiów zarówno pod względem instytucjonalnym, jak i personalnym. Zależność instytucjonalna wyrażała się w powierzeniu prezydium obsługi organizacyjno-technicznej oraz prawnej kolegium, którą wykonywały komórki karno-administracyjne usytuowane w wydziałach lub oddziałach społeczno-administracyjnych prezydiów rad narodowych ${ }^{21}$. Po reaktywowaniu w 1954 r. resortu spraw wewnętrznych utworzono wydziały orzecznictwa karno-administracyjnego, wchodzące w skład wojewódzkich zarządów spraw wewnętrznych ${ }^{22}$.

Całkowite uzależnienie organizacyjne kolegium od prezydium występowało także na etapie postępowania wykonawczego, gdyż orzeczenia i nakazy karne wykonywało prezydium rady narodowej właściwe według miejsca zamieszkania ukaranego ${ }^{23}$. Silne powiązania instytucjonalne kolegiów z administracją stwarzał przewidziany ustawą z 15 grudnia $1951 \mathrm{r}$. system nadzoru nad orzecznictwem karno-administracyjnym, sprawowany przez prezydia rad narodowych i Prezesa Rady Ministrów, a od końca 1954 r. przez Ministra Spraw Wewnętrznych za pomocą Biura Nadzoru nad Orzecznictwem Karno-Administracyjnym (Biuro Nadzoru).

${ }^{19}$ M. Kallas, A. Lityński, Historia ustroju i prawa Polski Ludowej, Warszawa 2003, s. 166.

${ }^{20}$ (Dz.U. Nr 14, poz. 130).

${ }^{21} \mathrm{~W}$ prezydiach wojewódzkich rad narodowych obsługa orzecznictwa karno-administracyjnego należała do referatów karno-administracyjnych wchodzących w skład wydziałów społeczno-administracyjnych. W prezydiach powiatowych, miejskich i dzielnicowych rad narodowych sprawy dotyczące postępowania karno-administracyjnego załatwiały oddziały społeczno-administracyjne. W pozostałych prezydiach rad narodowych obsługa kolegiów zajmowały się referaty ogólnoadministracyjne lub administracyjne. R. Rajkowski, op. cit., s. 136-137.

22 \& 5 uchwały nr 823 a Rady Ministrów z dnia 7 grudnia 1954 r. o zakresie działania Ministerstwa Spraw Wewnętrznych oraz jego organów terenowych (Mon. Pol. z 1955 r. nr 8, poz. 83).

${ }^{23}$ Zgodnie z postanowieniami art. 42 ust. 2 ustawy z 15 grudnia 1951 r. „Orzeczenia i nakazy karne wykonuje prezydium gminnej, miejskiej lub dzielnicowej rady narodowej właściwe według miejsca zamieszkania ukaranego". 
Wobec braku hierarchicznego podporządkowania kolegiów organom administracji nadzór ten miał postać wykonywanego przez prezydia „nadzoru bezpośredniego nad działalnością" kolegium istniejącego przy danym prezydium oraz prezydiach rad narodowych niższego stopnia. Ustawodawca nie sprecyzował, na czym tenże „,bezpośredni nadzór” miałby polegać, podobnie rzecz miała się w przypadku sprawowania przez Prezesa Rady Ministrów „Zwierzchniego nadzoru nad działalnością kolegiów”. Bardziej precyzyjnie określono nadzór nad orzecznictwem kolegiów sprawowany przez prezydia wojewódzkich rad narodowych, które otrzymały prawo udzielania „wytycznych dla orzecznictwa i kontroli ich wykonania" oraz uchylania w trybie nadzoru prawomocnych orzeczeń, w przypadku stwierdzenia ich nielegalności lub „oczywistej niesłuszności”"24. Oznaczało to możliwość uchylenia w trybie nadzoru każdego prawomocnego orzeczenia kolegium, jedynym ograniczeniem był zakaz uchylenia prawomocnego orzeczenia na niekorzyść osoby ukaranej lub uniewinnionej po upływie trzech miesięcy od uprawomocnienia się orzeczenia $^{25}$.

Nadrzędna pozycja prezydiów rad narodowych skutkowała zależnością pomiędzy poziomem funkcjonowania kolegiów a podejściem danego prezydium do zagadnień orzecznictwa karno-administracyjnego. Szczególne znaczenie przypisywano nadzorowi prezydiów nad pracą obsługującego kolegia aparatu karno-administracyjnego ${ }^{26}$ oraz kontroli wykonywania przez kolegia wytycznych dotyczaccych praktycznego wykonywania orzecznictwa. W pierwszych latach obowiązywania ustawy z 15 grudnia 1951 r. prezydia nie wykazywały troski „o poziom orzecznictwa karno-administracyjnego, o pracę kolegiów orzekających", z wyjątkiem traktowanej priorytetowo ze względów politycznych dziedziny dostaw obowiązkowych. Świadczyć o tym może fakt, iż w 1953 r. niektóre prezydia w ogóle nie omawiały polityki karno-administracyjnej, a ich aktywność ograniczała się do wprowadzania przyśpieszonego trybu postępowania w sprawach o niewykonanie dostaw obowiązkowych. Prezydia nie dbały o właściwą organizacje pracy kolegiów ani o szkolenie ich członków, pozostawiając „,w wielu województwach całokształt tej pracy aparatowi obsługującemu kolegia" ${ }^{27}$. Także podsumowując rok 1954, stwierdzono występowanie ,poważnych braków i wypaczeń w polityce k.a.”, wskazując jako jedna z przyczyn takiego stanu rzeczy „niedocenianie orzecznictwa k.a. przez prezydia rad narodowych i związaną z tym słabą pomoc dla kolegiów orzekających i aparatu k.a." Prezydiom rad narodowych zarzucano nieprzepro-

${ }^{24}$ M. Jaroszyński, Zagadnienia rad narodowych, Warszawa 1961, s. 229.

${ }^{25}$ E. Iserzon, Kierunki reformy prawa karno-administracyjnego, „Państwo i Prawo” 1961, nr 11, s. 771 .

${ }^{26}$ B. Wrzesińska, Prezydium rady a praca kolegium, „Poradnik dla Kolegiów Orzekających” („PdKO”) 1956, nr 1, s. 9.

${ }^{27}$ E. Dornfest, Przed wyborami do kolegiów orzekajacych, „Rada Narodowa” 1954, nr 5, s. 31. 
wadzanie systematycznej analizy orzecznictwa podległych im kolegiów, małe zainteresowanie szkoleniem członków kolegiów i „niewłaściwą pod względem jakościowym obsadę personalną aparatu k.a." Zastrzeżenia wysuwano zwłaszcza pod adresem prezydiów powiatowych rad narodowych, które ,zajęte zagadnieniem orzecznictwa na swoim szczeblu, przede wszystkim sprawami dostaw obowiązkowych, z pola widzenia zatraciły kolegia miejskie i gminne". Brak należytej kontroli i instruktażu skutkował tym, że kolegia najniższego szczebla „karały przede wszystkim nakazowo, omijając tym samym skuteczny środek wychowawczy, jakim jest rozprawa przed kolegium"28.

Uwaga prezydiów rad narodowych „koncentrowała się przede wszystkim na orzecznictwie z zakresu obowiązkowych dostaw", co wynikało z politycznego traktowania tych dostaw w kategoriach instrumentu walki klasowej na wsi. Natomiast ,orzecznictwo karno-administracyjne dotyczące zagadnień pozaskupowych, mimo iż stanowi około $80 \%$ ogółu wymierzonych kar, nie było przedmiotem należytej troski aparatu karno-administracyjnego". Ze względu na priorytetowe traktowanie dostaw obowiązkowych $\mathrm{w}$ tej dziedzinie pracy kolegiów najszybciej zaczęto realizować powstałą na fali tzw. odwilży politykę traktowania kar w kategoriach „,metody wychowania i dopomagania do wykonania konkretnych zadań rad narodowych" ${ }^{29}$. Wskazuje na to opinia Biura Nadzoru, którego zdaniem pełna realizacja założeń nowej polityki karno-administracyjnej miała miejsce jedynie w tzw. orzecznictwie skupowym, gdzie ,prezydia rad narodowych, organa prokuratury i Ministerstwa Skupu przejawiały większe zainteresowanie" pracą kolegiów ${ }^{30}$.

Rok 1956 przynosi wzrost zainteresowania prezydiów rad narodowych orzecznictwem karno-administracyjnym, gdyż prawie wszystkie wojewódzkie rady narodowe miały dokonać na sesjach lub posiedzeniach prezydium oceny orzecznictwa karno-administracyjnego, „wysuwając wiele postulatów zmierzających do podniesienia poziomu tej pracy, niejednokrotnie w postaci konkretnych wniosków zmierzających do znowelizowania ustawy z 15 XII 1951 r."’31. Zainteresowanie rad narodowych nie ograniczało się, jak dotychczas, do wysłuchania informacji o pracy kolegiów, lecz polegało także na wskazywaniu najważniejszych błędów w funkcjonowaniu kolegiów i wskazania środków służących eliminacji stwierdzonych uchybien ${ }^{32}$. Jako przykład zmiany podejścia prezydiów do oceny pracy kolegiów może posłużyć uchwała podjęta w lu-

\footnotetext{
${ }^{28}$ Sprawozdanie zbiorowe o orzecznictwie karno-administracyjnym za IV-ty kwartał $1954 \mathrm{r}$. Prezydium W.R.N. w Lublinie, IPN BU MSW I 526, s. 281-282.

${ }^{29}$ Analiza orzecznictwa w sprawach wykroczeń administracyjnych z wyłączeniem spraw dostaw obowiazkowych, IPN BU MSW I $11+2$, s. 311.

${ }^{30}$ Notatka informacyjna dla Kolegium Ministerstwa o przebiegu orzecznictwa karno-administracyjnego w 1955 roku, IPN BU MSW II 6443, s. 28.

${ }^{31}$ H. Chmielewski, Orzecznictwo karno-administracyjne w roku 1956, ,PdKO” 1957, nr 1-2, s. 3.

${ }^{32}$ B. Wrzesińska, op. cit., s. 9.
} 
tym 1956 r. przez prezydium Wojewódzkiej Rady Narodowej w Warszawie, w której poruszono problem całokształtu orzecznictwa karno-administracyjnego i środków służących poprawie poziomu jego funkcjonowania. Uchwała nakazywała przeprowadzenie dodatkowych wyborów uzupełniających celem zapewnienia właściwego składu społecznego kolegiów, zwłaszcza uwzględniania szerszego udziału kobiet. Prezydium WRN poruszyło w uchwale kwestie ograniczenia liczby wniosków o ukaranie kierowanych do kolegów oraz właściwej formy sporządzania zawiadomień, zalecając przeprowadzanie systematycznych narad z przedstawicielami władz, urzędów i instytucji nadsyłających zawiadomienia o ukaraniu. Specjalny rozdział uchwały poświęcono MO, której zalecono sumienne i wnikliwe opracowywanie wniosków o ukaranie, przewidując przeprowadzenie specjalnego szkolenia dla funkcjonariuszy Milicji w zakresie orzecznictwa karno-administracyjnego ${ }^{33}$.

III. Skład osobowy kolegium. Kształtowanie orzecznictwa kolegium w sposób pożądany przez prezydium stwarzały rozwiązania przewidujące piastowanie funkcji przewodniczącego kolegium przez członka prezydium oraz zastępcy przewodniczącego przez członka lub pracownika prezydium. Oprócz przewodniczącego i zastępcy w skład kolegium wchodzili członkowie, którzy rekrutowali się spośród radnych, aktywu społecznego i organizacji społecznych. W myśl zasady uspołecznienia orzecznictwa karno-administracyjnego reprezentowali oni tzw. czynnik społeczny. Liczba członków kolegiów nie była została określona przez ustawodawcę, stąd ustalały ją poszczególne prezydia rad narodowych w zależności od potrzeb swojego terenu. Wraz z przejęciem zwierzchniego nadzoru nad orzecznictwem karno-administracyjnym przez MSW wytyczne wydane w związku z wyborami do kolegiów w I kwartale 1955 r. wprowadziły zasadę, iż skład kolegiów przy gromadzkich rad narodowych wynosi 6 do 8 członków. Na szczeblu powiatowym kolegium liczyło od 15 do 30 członków, zaś w skład kolegium przy prezydium wojewódzkiej rady narodowej wchodziło 32 członków $^{34}$.

Zgodnie z zasadą kolegialności sprawy o wykroczenia były rozpatrywane na rozprawie przez trzyosobowy skład orzekający, którym powinien kierować przewodniczący kolegium lub jego zastępca ${ }^{35}$. Przewodniczącym składu orzekającego mógł być również wyznaczony przez przewodniczącego członek kolegium piastujący mandat radnego, przy czym nie musiał on posiadać wykształcenia prawniczego ani doświadczenia związanego z pracą $\mathrm{w}$ aparacie

${ }^{33}$ Jak Prezydium WRN w Warszawie pomaga kolegiom orzekajacym, „PdKO” 1956, nr 2-3, s. 23.

${ }^{34}$ Sprawozdanie Prezydium Wojewódzkiej Rady Narodowej w Koszalinie z przebiegu orzecznictwa karno-administracyjnego w I kwartale 1955 r., IPN BU MSW I 526, s. 320.

${ }^{35}$ M. Broniatowski, Perspektywy rozwoju orzecznictwa karno-administracyjnego, „Państwo i Prawo" 1962, nr 7, s. 73. 
administracji. Praktyka poszła w kierunku wyznaczania radnych na przewodniczącymi składów orzekających, ponieważ przewodniczący kolegiów i ich zastępcy nie brali udziału $\mathrm{w}$ rozprawach $\mathrm{z}$ racji obciążenia pracą biurowa, w tym wydawaniem orzeczeń w trybie nakazowym. Stąd dochodziło do sytuacji takich jak w powiecie Ostrołęka, gdzie według stanu na dzień 30 września 1955 r. ,przewodniczący kolegium powiatowego od początku roku ani razu nie brał udziału w posiedzeniach kolegium". Pomimo wyznaczania radnych na przewodniczących składów orzekających miały miejsce przypadki rozpatrywania spraw w składach niezgodnych z wymogami ustawy z 15 grudnia 1951 r., gdyż radni ,pomimo uprzedzenia o terminie rozpraw nie zawsze stawiali się na nie”. Przyczyn takiego stanu rzeczy upatrywano w „braku dyscypliny wśród członków kolegiów", stąd nawet w traktowanych w sposób priorytetowy sprawach o niewykonanie dostaw obowiązkowych płodów rolnych ,przewodniczącymi składów orzekających w wielu przypadkach były osoby nie będące radnymi" 36 .

Kolegialność orzecznictwa miała zastosowanie w ramach podstawowego trybu postępowania karno-administracyjnego, opartego na zasadzie kontradyktoryjności i przewidującego wydawanie orzeczeń po przeprowadzeniu rozprawy przed kolegium. Dwa pozostałe rodzaje postępowań przewidywały nakładanie kar za wykroczenia bez przeprowadzenia rozprawy. Pierwszym z nich było postępowanie nakazowe, w ramach którego przewodniczący kolegium powiatowego lub jego zastępca w drodze wydania nakazu karnego mógł zaocznie wymierzyć karę upomnienia, grzywny do 150 złotych lub do 3 dni pracy poprawczej ${ }^{37}$. Na szczeblu gmin i małych miast wydawanie nakazów karnych należało do kompetencji kolegiów i wprawdzie odbywało się kolegialnie, lecz również bez przeprowadzenia rozprawy. Inkwizycyjny charakter postępowania nakazowego miała rekompensować możliwość odwołania się od nakazu karnego do kolegium przy prezydium rady narodowej wyższego stopnia ${ }^{38}$.

$\mathrm{Z}$ kolei w ramach postępowania mandatowego organy Milicji Obywatelskiej mogły wymierzać za drobne przewinienia kary grzywny w wysokości do 20 złotych w przypadku schwytania sprawcy na gorącym uczynku, pod warunkiem że sprawca zgodził się na niezwłoczne uiszczenie grzywny wymierzonej mandatem. Brak zgody sprawcy na uiszczenie mandatu oznaczał skierowanie sprawy na drogę postępowania nakazowego i wymierzenie kary w drodze wydania nakazu karnego ${ }^{39}$.

${ }^{36}$ Analiza udziału orzecznictwa karno-administracyjnego w 1955 r. w realizacji planów dostaw obowiązkowych, IPN BU MSW I 11 + 2, s. s. 332.

${ }^{37}$ J. Jasiński, Krytycznie o ustawie przeciw chuliganom, „Prawo i Życie” 1958, nr 13, s. 4.

${ }^{38}$ Z. Rybicki, Gospodarcze aspekty orzecznictwa karno-administracyjnego, „Przegląd Ustawodawstwa Gospodarczego" 1952, nr 9, s. 322.

${ }^{39}$ Sprawozdanie stenograficzne z 99 posiedzenia Sejmu Ustawodawczego w dniu 15 grudnia $1951 r$., łam 34-35. 
Kolegialny tryb rozpatrywania spraw o wykroczenia był zbliżony do struktury sądu orzekającego z udziałem czynnika społecznego ${ }^{40}$, jednak formalną niezawisłość członków składów orzekających w wykonywaniu orzecznictwa ograniczał system powiązań personalnych kolegiów z terenowymi organami administracji państwowej. Prezydia rad narodowych miały decydujący wpływ na kształtowanie składu osobowego kolegium, gdyż wprawdzie wyboru członków kolegium dokonywała rada narodowa, lecz była przy tym związana ustaleniami prezydium dotyczącymi zarówno kręgu kandydatów, jak i liczby członków kolegium ${ }^{41}$. Ustawa z 15 grudnia $1951 \mathrm{r}$. nie wypowiadała się w sprawie kwalifikacji kandydatów na członków kolegiów, lecz uczyniło to wydane na podstawie delegacji ustawowej rozporządzenie Rady Ministrów ${ }^{42}$, w myśl postanowień którego osoby wykonujące określone funkcje publiczne zostały pozbawione możliwości ubiegania się o bycie członkiem kolegium ${ }^{43}$. Innych ograniczeń nie przewidziano, stąd członkiem kolegium mógł zostać każdy zamieszkały w okręgu działania kolegium pełnoletni obywatel, korzystający z pełni praw obywatelskich i publicznych. Wydana w związku z wejściem w życie ustawy z 15 grudnia 1951 r. broszura szkoleniowa zalecała przeprowadzanie wnikliwej i sumiennej analizy kandydatów na członków kolegiów i ostateczne ustalenie list kandydatów w porozumieniu ,z komitetami partyjnymi, związkami zawodowymi, Związkiem Samopomocy Chłopskiej oraz Ligą Kobiet", celem zapewnienia szerokiego udziału kobiet w orzecznictwie karno-administracyjnym ${ }^{44}$.

W pierwszej kolejności na listach kandydatów do kolegiów mieli być umieszczani robotnicy i pracujący chłopi, zwłaszcza ,,przodownicy pracy, aktywiści społeczni, robotnicy z fabryk, chłopi mało- i średniorolni, chłopi ze spółdzielni produkcyjnych" ${ }^{45}$. Układając listę kandydatów, prezydium rady narodowej musiało umieścić na niej radnych, gdyż zgodnie z postanowieniami ustawy z 15 grudnia 1951 r. członkowie kolegiów powinni rekrutować się za-

${ }^{40}$ Przewodniczący kolegium lub jego zastępca dokonywali czynności odpowiadających czynnościom prezesa sądu. Członkowie kolegium będący radnymi na mocy upoważnienia ze strony przewodniczącego mogli przewodniczyć rozprawom, stanowiąc swego rodzaju odpowiednik sędziów, zaś pozostali członkowie kolegium na podobieństwo ławników pełnili funkcję członków składu orzekającego, decydując zarówno o winie jak i o karze. J. Skupiński, op. cit., s. 114-115.

${ }^{41}$ M. Jaroszyński, op. cit., s. 226.

${ }^{42}$ Rozporządzenie Rady Ministrów z dnia 16 grudnia 1951 r. w sprawie trybu wybierania i odwoływania członków kolegiów przy prezydiach rad narodowych (Dz. U. nr 66, poz. 455).

${ }^{43}$ Kandydatami na członków kolegiów nie mogły być:

a) osoby zajmujące stanowiska merytoryczne w sądownictwie i prokuraturze (łącznie z aplikantami) oraz adwokaci i aplikanci adwokaccy, a także ławnicy,

b) żołnierze w służbie czynnej

c) pracownicy resortu bezpieczeństwa publicznego,

d) lekarze zatrudnieni w pełnym wymiarze godzin w lecznictwie uspołecznionym.

${ }^{44}$ O pracy kolegiów..., s. 17.

${ }^{45}$ Ibidem. 
równo spośród radnych, jak i spoza ich grona. Ustawodawca w pewnym sensie preferował radnych jako członków kolegiów, przewidując możliwość wyznaczenia radnego na przewodniczącego składu orzekającego, w sytuacji gdy przewodniczący kolegium lub jego zastępca nie byli w stanie zasiadać w składzie orzekającym. Z kolei wspomniana broszura szkoleniowa zalecała typowanie na członków kolegiów osób niebędących radnymi, ze względu na obowiązki radnych związane z pracą w komisjach rad narodowych i inne funkcje społeczne. Praktyka poszła zdecydowanie w kierunku faworyzowania radnych jako kandydatów na członków kolegiów, na co wskazuje chociażby sprawozdanie opisujące przebieg wyborów do kolegiów gromadzkich na terenie województwa koszalińskiego w I kwartale 1955 r. Jako poważne niedociąnnięcie „,na odcinku wyboru szczególnie kolegiów gromadzkich” oceniono występujące na terenie województwa „tendencje typowania na członków kolegium spoza radnych”. Wprawdzie tylko „w trzech gromadzkich radach narodowych wybrano do Kolegium ludzi spoza rady”, to i tak uznano że zaszła „konieczność dokonania zmiany składu kolegium w tych gromadach"46.

Osoby umieszczone przez prezydium na liście kandydatów nie mogły odmówić wpisania na listę, gdyż członkostwo w kolegium było obowiązkiem obywatelskim. Za udział w pracach kolegium, nie przysługiwało specjalne wynagrodzenie, a jedynie wzorem ławników sądowych prawo do wynagrodzenia za czas pełnienia obowiązków w kolegium lub zwrot utraconych zarobków. Kandydaci na członków kolegiów mogli jedynie wnosić o skreślenie z listy ze względu na stan zdrowia, ważny interes publiczny lub dotychczasowe pełnienie funkcji członka kolegium ${ }^{47}$.

Lista kandydatów była następnie przedstawiana radzie narodowej, która na sesji dokonywała wyboru członków kolegiów na okres od roku do dwóch lat, gdyż wspomniane rozporządzenie Rady Ministrów przewidywało wybór kolegium ,na okres do końca roku kalendarzowego, następującego po roku, w którym dokonano wyboru" ${ }^{\prime 4}$. Na wniosek przewodniczącego kolegium istniała możliwość odwołania przez radę narodową osób wybranych w skład kolegium, jednak rozporządzenie nie określało przyczyn uzasadniających sporządzenie takiego wniosku. Broszura szkoleniowa zalecała złożenie wniosku o odwołanie członka kolegium, który „nie wykonuje sumiennie swoich obowiązków, bez usprawiedliwionych powodów nie stawia się na posiedzenia kolegium, często spóźnia się". Środkiem oddziaływania na członków kolegiów służącym zapewnieniu dyscypliny uczestnictwa w posiedzeniach kolegium, były nakładane przez przewodniczącego kary porządkowe oraz obowiązek

\footnotetext{
${ }^{46}$ Sprawozdanie Prezydium Wojewódzkiej Rady Narodowej w Koszalinie z przebiegu orzecznictwa karno-administracyjnego w I kwartale 1955 r., IPN BU MSW I 526, s. 350.

${ }^{47}$ O pracy kolegiów..., s. 17-18, 29.

${ }^{48} \S 1$ ust. 1 rozporządzenia Rady Ministrów dnia 16 grudnia 1951 r. w sprawie trybu wybierania i odwolywania członków kolegiów przy prezydiach rad narodowych (Dz. U. nr 66, poz. 455).
} 
zwrotu kosztów postępowania wynikłych z nieusprawiedliwionej absencji członka kolegium $^{49}$.

Wybory do kolegiów. Wprowadzająca socjalistyczne rozwiązania w zakresie orzecznictwa karno-administracyjnego ustawa z 15 grudnia $1951 \mathrm{r}$. wchodziła w życie z początkiem kwietnia 1951 r., co wymagało szeregu prac przygotowawczych. Zadaniem tym obarczono Zespół II Prezydium Rady Ministrów, czyli organ za pośrednictwem którego Prezes Rady Ministrów sprawował zwierzchni nadzór nad orzecznictwem karno-administracyjnym. Najważniejszy punkt prac przygotowawczych stanowiły przewidziane na luty 1952 r. wybory przewodniczących, ich zastępców oraz członków kolegiów przez rady narodowe. Wytyczne Zespołu II Prezydium Rady Ministrów stanowiły, iż „dobierać należy kandydatów, którzy dają gwarancję należytego wypełniania obowiązków nałożonych na nich nową ustawą i stojących na odpowiednim poziomie politycznym" 50 . W przeprowadzonych w lutym $1952 \mathrm{r}$. wyborach rady narodowe powołały do pracy w kolegiach około 37 tysięcy osób, z czego 30\% stanowili preferowani przez ustawodawcę radni. Skład polityczny nowo utworzonych kolegiów cechowała względna równowaga osób bezpartyjnych (49\%) oraz członków Partii komunistycznej (45\%) i ZMP (6\%). Decydujące znaczenie dla rzeczywistego układu sił miał fakt, że przewodniczący kolegiów i ich zastępcy rekrutowali się z reguły spośród lokalnego aktywu partyjnego. Zgodnie z założeniem demokratyzacji orzecznictwa karno-administracyjnego 14\% składu osobowego kolegiów stanowiły kobiety, lecz ich rola ograniczała się z reguły do pełnienia funkcji członka składu orzekającego. Kompetencje niezbędne do przewodniczenia rozprawom posiadali $\mathrm{z}$ reguły mężczyźni z racji pełnienia funkcji przewodniczącego kolegium, jego zastępcy lub radnego ${ }^{51}$.

Pierwsze wybory składów kolegiów zostały przeprowadzone w sposób formalistyczny, gdyż listy kandydatów były odczytywane na sesjach rady i w całości zatwierdzane bez wcześniejszej prezentacji poszczególnych osób. Radni wybierali do kolegiów osoby zupełnie im nie znane, których typowanie przez organizacje społeczne i zakłady pracy miało charakter mechaniczny. Układające listy kandydatów prezydia rad narodowych czyniły to w pośpiechu i bez należytego przygotowania, co prowadziło do powoływania w skład kolegiów „osób o niewłaściwej postawie polityczno-ideowej: pijaków, ludzi o złej przeszłości, popleczników kułackich" 52 . Dotyczyło to zwłaszcza kolegiów szczebla gminnego, gdzie wobec braku dostatecznej liczby aktywistów wy-

\footnotetext{
${ }^{49}$ Stanowił o tym art. 5 ust. 6 ustawy z 15 grudnia $1951 \mathrm{r}$.

${ }^{50} \mathrm{E}$. Dornfest, $W$ jaki sposób będziemy realizować..., s. 21-22.

${ }^{51}$ Analiza orzecznictwa karno-administracyjnego w latach 1952-53 i 54, IPN BU MSW II 524,

${ }^{52}$ Przed wyborami do kolegiów orzekajacych, „Rada Narodowa” 1954, nr 5, s. 31.
} s. 12 . 
wodzących się spośród mało- i średniorolnych chłopów sumiennie wykonujących obowiązki na rzecz państwa, w składach orzekających kolegiów zasiadali ludzie zalegający z dostawami zboża. Przykładowo w składzie orzekającym jednego z kolegiów na terenie województwa wrocławskiego w $1953 \mathrm{r}$. zasiadał zastępca przewodniczącego prezydium gminnej rady narodowej, który ,zalegał z dostawą zboża, a ponadto osłaniał po kumotersku innych zalegających z dostawami rolników". Podobnie wyglądała sytuacja w innych powiatach województwa wrocławskiego, stąd prezydia rad narodowych podjęły działania w kierunku odwołania ,popleczników kułackich i powołania na ich miejsce przodujących chłopów"53.

Wprawdzie na listach kandydatów do kolegiów umieszczano w pierwszej kolejności aktywistów partyjnych i społecznych, lecz kierując się kryterium poprawności klasowej, prezydia rad narodowych nie brały pod uwagę znacznego obciążenia tzw. aktywu pracą zawodową i społeczną, co w istotny sposób utrudniało tym osobom należyte wykonywanie funkcji członka kolegium. Dlatego też dokonując oceny działalności powołanych do życia w kwietniu $1952 \mathrm{r}$. kolegiów, w szeregu przypadków stwierdzono, iż ,poważnym błędem było zbyt mechaniczne typowanie przez organizacje masowe kandydatów spośród ludzi przeciążonych już pracą społeczną, np. posłowie na Sejm, ławnicy sądów powszechnych itd." ${ }^{54}$. Nieuwzględnienie tego rodzaju okoliczności przy typowaniu kandydatów pociągało za sobą faktyczną niemożność wykonywania funkcji członka składu orzekającego i zmuszało prezydia rad narodowych do składania wniosków o odwołanie członka kolegium oraz dokonanie wyboru innej osoby na jego miejsce. Dosyć często odnotowywano także przypadki lekceważącej postawy części członków kolegiów, którzy „nie wykonują swoich obowiązków spóźniając się lub w ogóle nie przybywając na posiedzenia"55. Wskazuje na to chociażby uchwała Wojewódzkiej Rady Narodowej w Kielcach z października 1952 r. wspominająca o ,znacznej absencji członków kolegiów notowanej na wszystkich szczeblach, wpływającej hamująco na szybkie orzecznictwo" ${ }^{56}$. Wzmocnieniu dyscypliny i poczucia odpowiedzialności za sprawne funkcjonowanie kolegiów wśród tych członków, którzy „nie wykonują swoich obowiązków spóźniając się lub w ogóle nie przybywając na posiedzenia", służyło nie tylko nakładanie kar porządkowych, lecz także stosowanie „środków perswazji i przekonywania”. Praktyka miała wykazać, że środki wychowawcze, takie jak „konferencje koordynacyjne, a przede wszystkim indywidualne rozmowy z poszczególnymi członkami Kolegium" przynoszą lepsze

${ }^{53}$ Z. Mazur, Kolegia orzekajace $w$ woj. wrocławskim w walce o wykonanie dostaw obowiazkowych, ,Rada Narodowa” 1953, nr 21, s. 22-23.

${ }^{54}$ J. Garlicki, Analizujemy pracę kolegium orzekajacego, „Rada Narodowa” 1954, nr 10, s. 28.

${ }^{55}$ R. Rajkowski, op. cit., s. 135.

${ }^{56}$ Uchwała WRN w Kielcach nr 10 z dnia 20 października 1952 r. o orzecznictwie karno-administracyjnym (Dz.U. WRN w Kielcach nr 12, poz. 61). 
rezultaty niż relatywnie niewysokie kary pieniężne nakładane przez przewodniczącego kolegium ${ }^{57}$.

Przyczyn niskiej frekwencji na posiedzeniach kolegiów upatrywano także w ,niedocenianiu znaczenia kolegiów, ich działalności” przez kierownictwo zakładów pracy. Zakłady pracy „częstokroć nie zezwalały, a co najmniej utrudniały pracownikom-członkom kolegium udział w rozprawach", co prowadziło do znacznego opóźnienia w rozpoczynaniu rozpraw i przeciągania ich zakończenia do późnych godzin nocnych ${ }^{58}$. Niska frekwencja na posiedzeniach kolegiów powodowała przeciążenie pracą tych nielicznych składów orzekających, których członkowie pozostawali do stałej dyspozycji przewodniczącego kolegium. Wskutek braku czasu na dokładne zapoznanie się z aktami przekazanych naprędce spraw członkowie składów orzekających przeprowadzali rozprawy w sposób „mechaniczny i pobieżny”, wydając orzeczenia formalistyczne „bez zbadania okoliczności towarzyszących wykroczeniu, bez analizy warunków bytowych winnego i wpływu otoczenia". Oparcie funkcjonowania kolegiów na zaledwie kilku będących stale do dyspozycji składach orzekających prowadziło do sytuacji określanej jako ,zrutynizowanie niektórych członków kolegiów". W rutynowym wykonywaniu orzecznictwa przez tych samych członków kolegiów upatrywano niebezpieczeństwo przejęcia przez nich metod i sposobu pracy ,,administracyjnego urzędowania" ${ }^{59}$, a przecież u podstaw socjalistycznej reformy orzecznictwa karno-administracyjnego z grudnia $1951 \mathrm{r}$. legła idea rozpatrywania spraw o wykroczenia przez czynnik społeczny.

Nierzetelne sporządzanie list kandydatów do kolegiów powodowało również „duże braki w składach kolegiów” pod względem pochodzenia społecznego ich członków, zwłaszcza w kolegiach szczebla powiatowego, gdzie przeważali pracownicy umysłowi. W zdecydowanej mniejszości pozostawali robotnicy i chłopi, chociaż to właśnie ich udział w pracach kolegiów miał dawać wyraz uspołecznieniu orzecznictwa karno-administracyjnego. Opisaną sytuację obrazuje przykład z województwa białostockiego, gdzie na szczeblu powiatu było „ogółem 236 członków, z czego tylko 21 chłopów, a aż 165 pracowników umysłowych". Z kolei na szczeblu gminnym w składach kolegiów tego województwa niemalże połowę stanowili pracownicy umysłowi, gdyż na „1263 członków kolegiów prezydiów GRN... pracowników umysłowych było 601, w tym 353 , czyli blisko $60 \%$ urzędników prezydiów GRN". Pełniące kluczową rolę w systemie orzecznictwa karno-administracyjnego, kolegia szczebla po-

${ }^{57}$ J. Garlicki, Z doświadczeń kolegium orzekajacego $w$ sprawach karno-administracyjnych, „Rada Narodowa” 1952, nr 19, s. 21.

58 J. Chełmiński, J. Malinowski, Otrzymałem wezwanie do kolegium karno-administracyjnego, Warszawa 1957, s. 62.

59 J. Garlicki, Analizujemy prace kolegium orzekajacego, „Rada Narodowa” 1954, nr 10, s. 27-28. 
wiatowego były silnie upartyjnione, na co wskazuje chociażby przykład kolegium przy prezydium Powiatowej Rady Narodowej w Puławach, ,gdzie na 50 członków kolegium jest aż 35 członków PZPR, a tylko 12 bezpartyjnych i 2 członków ZSL" ${ }^{60}$.

Pierwsza kadencja kolegiów orzekających upłynęła wraz z końcem 1953 r., co oznaczało konieczność przeprowadzenia w pierwszym kwartale roku $1954 \mathrm{r}$. wyborów członków kolegiów. Wybory ponownie miały charakter formalny, gdyż rady narodowe nie dokonując oceny funkcjonowania orzecznictwa karno-administracyjnego na ich terenie, ograniczały się do zatwierdzenia listy kandydatów przedstawionych przez prezydia. Nie przeprowadzano dyskusji nad poszczególnymi kandydaturami, stąd wszystkie osoby umieszczone na listach kandydatów zostały w sposób mechaniczny wybrane do kolegiów. W porównaniu z poprzednimi wyborami liczba członków kolegiów wzrosła o 10 tysięcy osób, co było posunięciem obliczonym na poprawę frekwencji podczas posiedzeń składów orzekających. Dotychczasowe doświadczenia wykazały, iż optymalna liczba członków kolegiów to taka, przy której jednego członka kolegium wzywa się na posiedzenia nie częściej niż dwa razy w miesiącu ${ }^{61}$. Skład wybranych w 1954 r. kolegiów nie uległ większym zmianom w porównaniu z poprzednią kadencją, gdyż 30\% członków kolegiów stanowili radni, 44\% członków należało do PZPR, 8\% do ZMP, zaś udział kobiet wzrósł do 16\% ${ }^{62}$. Wyniki wyborów zostały przyjęte z zadowoleniem przez Zespół II Prezydium Rady Ministrów, gdyż „wybrani zostali obywatele najbardziej wyrobieni społecznie i politycznie, cieszący się szacunkiem i poważaniem wśród otoczenia, dający rękojmię należytego wykonywania tak odpowiedzialnej funkcji”"63.

Kadencja kolegiów powołanych do życia w lutym i marcu 1954 r. uległa skróceniu, gdyż w związku z pierwszymi w Polsce Ludowej wyborami rad narodowych władze uznały za pożądane, ,aby powołane zostały nowe składy kolegiów karno-administracyjnych". Wybory do rad narodowych miały miejsce w grudniu 1954 r. i po raz pierwszy odbyły się na szczeblu gromad, które utworzono w miejsce dotychczasowych gmin. Utworzenie gromad rodziło konieczność powołania kolegiów przy prezydiach gromadzkich rad narodowych ${ }^{64}$, wskutek czego liczba członków kolegiów miała wzrosnąć do około 100 tysięcy ${ }^{65}$.

${ }^{60}$ Z. Mazur, op. cit., s. 22-23.

${ }^{61}$ E. Dornfest, Doświadczenia pierwszego okresu stosowania ustawy o orzecznictwie karno-administracyjnym, „Rada Narodowa” 1952, s. 27.

${ }^{62}$ Analiza orzecznictwa karno-administracyjnego w latach 1952 - 53 i 54, IPN BU MSW II 524, s. 12.

${ }^{63}$ Po wyborach do kolegium, „Biuletyn dla Członków Kolegiów Karno-Administracyjnych”, 1954 , nr 1, s. 5.

${ }^{64}$ Pismo Biura Nadzoru nad Orzecznictwem Karno-Administracyjnym MSW w sprawie wyborów do kolegiów orzekających w 1955 r., IPN BU MSW II 6438, s. 14.

${ }^{65}$ Analiza orzecznictwa karno-administracyjnego w latach 1952-53 i 54, IPN BU MSW II 524, s. 12 
W pierwszej kolejności (koniec stycznia, luty 1955 r.) przeprowadzono wybory kolegiów szczebla powiatowego i wojewódzkiego, których organizacja nie nastręczała większych problemów z racji posiadania przez prezydia rad narodowych doświadczeń nabytych w trakcie poprzednich wyborów. Wybory do kolegiów gromadzkich odbyły się marcu i kwietniu 1955 r. w oparciu o zarządzenie Ministra Spraw Wewnętrznych, chociaż w niektórych województwach gromadzkie rady narodowe utworzyły kolegia jeszcze w styczniu 1955 r. Sytuacja taka miała miejsce w województwie koszalińskim, gdzie nowo utworzone gromadzkie rady narodowe domagały się powołania kolegiów i ,niektóre zaczęły już same dokonywać wyborów do kolegiów orzekających". W związku z tym Prezydium Wojewódzkiej Rady Narodowej wydało zarządzenie określające tryb wyboru kolegiów gromadzkich, miejskich i powiatowych, „którego treść pokrywała się z zarządzeniem Ministra Spraw Wewnętrznych o wyborze kolegiów orzekających”. Po otrzymaniu na początku lutego 1955 r. zarządzenia Ministra Spraw Wewnętrznych ,wstrzymano wybory kolegiów w tych gromadach i powiatach, w których nie zostały dokonane wybory celem przygotowania i przeprowadzenia wyborów zgodnie z wytycznymi Ministerstwa Spraw Wewnętrznych"66.

Opracowane przez Biuro Nadzoru wytyczne miały na celu przeprowadzenie kampanii wyborczej w sposób wykluczający mechaniczne typowanie kandydatów i formalny ich wybór przez rady narodowe. Wytyczne nakazywały umieszczanie na listach kandydatów do kolegiów radnych oraz członków prezydium gromadzkiej rady narodowej, w sposób drugorzędny traktując zagadnienie udziału w orzecznictwie karno-administracyjnym tzw. aktywu społecznego, gdyż nie był on zbyt liczny w małych terytorialnie gromadach. Kandydatem na przewodniczącego kolegium miał być przewodniczący rady narodowej lub jej sekretarz, zaś zastępcą przewodniczącego powinien zostać członek prezydium gromadzkiej rady narodowej. Po ułożeniu listy kandydatów prezydium miało się zająć przygotowaniem sesji rady narodowej, w szczególności poinformować radnych o planowanych podczas sesji wyborach kolegium. Za wskazane uznano zaproszenie na sesję rady narodowej „,przedstawiciela najbliższego posterunku Milicji Obywatelskiej, O.R.M.O., Straży Leśnej, Komendanta Ochotniczej Straży Pożarnej”. Najważniejszym punktem tych przygotowań było opracowanie przez prezydium referatu wyjaśniającego radnym zadania kolegium orzekającego oraz specyfikę jego pracy. Referat powinien zawierać omówienie dotychczasowych doświadczeń i pracy kolegium przy prezydium gminnej rady narodowej, a zwłaszcza wskazywać ,złe strony w pracy byłego kolegium gminnego i przestrzec przyszłe kolegium przed powtarzaniem tych błędów". Ważnym punktem referatu była

${ }^{66}$ Sprawozdanie Prezydium Wojewódzkiej Rady Narodowej w Koszalinie z działalności orzecznictwa karno-administracyjnego za I kwartał 1955 r., IPN BU MSW I 526, s. 349-350. 
prezentacja istotnych spraw w życiu danej gromady, połączona $\mathrm{z}$ analizą najczęściej występujących wykroczeń, na które przyszłe kolegium powinno zwracać szczególną uwagę. Wytyczne jako przykład zadań stojących przed kolegium gromadzkim podawały „konieczność podniesienia stanu sanitarnego w gminie albo konieczność zwalczania naruszeń spokoju i porządku publicznego". Po wygłoszeniu referatu zakładano dyskusję, podczas której radni powinni zgłaszać uwagi i propozycje w sprawach, „w których oczekują pomocy ze strony kolegium"67.

Kolejnym punktem sesji gromadzkiej rady narodowej poświęconej wyborom kolegium było przedstawienie przez prezydium listy kandydatów na członków kolegium celem wyrażenia przez radnych opinii o kandydatach. Wytyczne zakładały możliwość odrzucenia poszczególnych kandydatur i wysunięcie w ich miejsce innych osób, co dotychczas nie miało miejsca wskutek formalistycznego przeprowadzania wyborów. Skład kolegium, liczący od 6 do 9 osób, gromadzka rada narodowa ustalała w głosowaniu jawnym.

W wyniku wyborów przeprowadzonych w lutym, marcu i kwietniu $1955 \mathrm{r}$. powołano do życia kolegia gromadzkie i zwiększono liczbę członków kolegiów szczebla powiatowego. Liczba „,członków kolegiów wzrosła z około 45000 w 1954 roku do 99142 w roku 1955”, z czego w skład kolegiów gromadzkich weszło 67601 osób $^{68}$. Kampania wyborcza różniła się od wyborów przeprowadzanych w poprzednich latach, gdyż po raz pierwszy przeprowadzono na sesjach rad narodowych dyskusję o pracy kolegiów, w której oprócz radnych zabierali głos także aktywiści społeczni. W sprawozdaniach z poszczególnych województw podkreślano, iż „kandydatów typowały organizacje społeczne, a z każdym z nich została przeprowadzona rozmowa przez pracowników aparatu K.A.” Z kolei wybory członków kolegiów „odbywały się nierzadko przy ożywionej dyskusji” ${ }^{\circ 9}$, podczas której miały miejsce przypadki usuwania z list kandydatów osób niecieszących się zaufaniem rady narodowej. Zdaniem Biura Nadzoru odejście od mechanicznego stylu przeprowadzania wyborów przyniosło „lepszy skład socjalny kolegiów”. Zwiększyła się liczba robotników i chłopów, którzy stanowili, odpowiednio, 17,9\% oraz 47,1\% członków kolegiów, chociaż w województwach o charakterze rolniczym chłopi stanowili przeważającą część członków kolegiów ${ }^{70}$. Zasiadający z reguły

${ }^{67}$ Pismo Biura Nadzoru nad Orzecznictwem Karno-Administracyjnym MSW dotyczące wyborów do kolegiów k.a. przy prezydiach gromadzkich rad narodowych, IPN BU MSW I 523, s. 2.

${ }^{68}$ Kolegia powiatowe liczyły 14138 członków, kolegia w miastach 15 576, zaś w skład kolegiów wojewódzkich weszło 1827 osób. Członkowie kolegiów karno-admin. w 1955 r., IPN BU MSW I $11+2$, s. 301.

${ }^{69}$ Sprawozdanie Prezydium Wojewódzkiej Rady Narodowej w Zielonej Górze z przebiegu orzecznictwa karno-administracyjnego w I kwartale 1955 r., INP BU MSW I 525, s. 402.

${ }^{70}$ Przykładowo w województwie lubelskim w skład kolegiów powołano 9386 osób, w tym 5288 chłopów indywidualnych oraz 449 robotników i pracowników PGR i 498 członków spółdzielni produkcyjnych. Ze względu na rolniczy charakter województwa wybrano tylko 747 robotników i 2405 
w kolegiach gromadzkich członkowie spółdzielni produkcyjnych i pracownicy PGR-ów stanowili 3,8\% składu osobowego kolegiów, natomiast aż 30,7\% członków kolegiów było pracownikami umysłowymi. Zgodnie z wytycznymi Biura Nadzoru w pierwszej kolejności wybierano radnych, stąd ich udział w ogólnej liczbie członków kolegiów wynosił 64,6\%. Zdecydowana większość członków kolegiów została wybrana po raz pierwszy, gdyż osoby posiadające doświadczenie wyniesione $\mathrm{z}$ pracy $\mathrm{w}$ kolegiach poprzednich kadencji stanowiły jedynie $16,3 \%$. Najsłabiej pod tym względem obsadzone były kolegia gromadzkie, w skład których weszło niespełna 10\% członków byłych kolegiów przy prezydiach gminnych rad narodowych ${ }^{71}$.

Pomimo udzielania wytycznych i kontroli przebiegu wyborów przez pracowników Biura Nadzoru uznano, że ,zadania postawione w kampanii wyborczej nie wszędzie zostały w pełni wykonane”, gdyż „,szereg prezydiów r.n. potraktowało wybory formalnie, nie przeprowadzając analizy orzecznictwa"72. W niektórych powiatach składy kolegium nie zostały dobrane należycie pod względem pochodzenia społecznego członków, ze względu na zbyt małą liczbę robotników i chłopów dokonano wymiany części członków kolegiów m.in. w powiecie radomskim. Przy układaniu list kandydatów prezydia rad narodowych w niedostatecznym stopniu uwzględniły udział kobiet w wykonywaniu orzecznictwa karno-administracyjnego, wskutek czego kobiety stanowiły $14,7 \%$ członków kolegium ${ }^{73}$.

Wybrane wówczas kolegia funkcjonowały do końca 1956 r., czyli ich kadencja przypadła na przełomowy dla powojennych dziejów Polski czas odwilży i przemian społeczno-politycznych. Pod wpływem tych wydarzeń dokonano przestawienia kolegiów na „metody pracy szeroko uwzględniające elementy profilaktyczne i wychowawcze", w miejsce nadmiernej represyjności cechującej orzecznictwo karno-administracyjnego okresu stalinowskiego $^{74}$. Zdaniem Biura Nadzoru przyczyniła się do tego właściwa postawa przeważającej większości członków kolegiów, „należycie doceniających zadania, jakie powierzyło im społeczeństwo". Członków kolegiów miała cechować lepsza niż dotychczas znajomość prawa i potrzeb swojego terenu oraz zaangażowanie w wykonywanie powierzonych im przez społeczeństwo zadań. Wprawdzie nie wszyscy wybrani do kolegiów „zdali ten społeczny egzamin”,

pracowników umysłowych. Sprawozdanie z orzecznictwa karno-administracyjnego na terenie województwa lubelskiego za 1955 rok, IPN BU MSW I 526, s. 87.

${ }^{71} \mathrm{Na}$ ogólną liczbę 67601 członków kolegiów gromadzkich doświadczenie wyniesione z pracy w byłych kolegiach gminnych posiadało jedynie 6669 osób. Członkowie kolegiów karno-admin. w 1955 r., IPN BU MSW I 11 + 2, s. 301.

${ }^{72}$ Notatka informacyjna dla Kolegium Ministerstwa o przebiegu orzecznictwa karno-administracyjnego w 1955 r., IPN BU MSW II 6443, s. 30.

${ }^{73}$ Ibidem, s. 31.

${ }^{74}$ Notatka informacyjna dla Kolegium Ministerstwa o przebiegu orzecznictwa karno-administracyjnego w 1956 r., IPN BU MSW II 4, s. 282. 
lecz większość z nich „nie szczędząc czasu, narażając się na przykrości ze strony tych, których karali”, okazywała „,istotną pomoc w codziennej pracy rad narodowych". W wyniku odejścia od formalistycznego stylu przeprowadzania wyborów kolegia dysponowały „wielu ofiarnymi, wyrobionymi kompletami orzekającymi", a tworzący te składy orzekające obywatele z racji zaangażowania i nabytego doświadczenia mieli w kolejnych kadencjach stanowić trzon kadrowy orzecznictwa karno-administracyjnego, uzupełniany „nowymi odpowiedzialnymi i poważnymi obywatelami, doceniającymi znaczenie porządku publicznego"75.

Optymistyczna ocena zaangażowania członków kolegiów łączyła się z podnoszoną na fali wydarzeń 1956 r. krytyką rozwiązań ustawy z 15 grudnia 1951 r. dotyczących m.in. trybu powoływania i organizacji pracy kolegiów orzekających. Przeprowadzone w drugiej połowie 1956 r. przez Ministerstwo Kontroli Państwowej badania orzecznictwa karno-administracyjnego miały wykazać, iż ,przepisy zawarte w ustawie z 1951 r. w znacznym stopniu sa obecnie nieaktualne, a nawet $\mathrm{w}$ niektórych wypadkach stanowią jedną z przyczyn hamujących pracę kolegiów" 76 . Uwaga ta dotyczyła m.in. procedury wyborów kolegiów, która nie gwarantowała właściwego doboru członków kolegiów pod względem ich przygotowania fachowego, lecz pozostawiała prezydium rad narodowych dużą swobodę w układaniu list kandydatów. Klimat polityczny okresu stalinowskiego powodował, iż podstawowym kryterium branym pod uwagę przy ustalaniu składu osobowego kolegiów było pochodzenie społeczne kandydatów, członkostwo w partiach politycznych i organizacjach społecznych, przynależność do tzw. aktywu społecznego. Wskutek braku dostatecznej liczby osób posiadających kwalifikacje fachowe do przewodniczenia składom orzekającym kolegiów, funkcje te pełnili z reguły zupełnie do tego nieprzygotowani radni, którymi wyręczali się przewodniczący kolegiów zaangażowani w bieżącą pracę prezydium rady narodowej. Wymóg przewodniczenia rozprawie przez członka kolegium piastującego mandat radnego nie był zresztą powszechnie respektowany, gdyż jeszcze w 1955 r. kolegia powiatowe rozpatrywały sprawy w składach ,niezgodnych z ustawą o orzecznictwie $\mathrm{k}-\mathrm{a}$, tj. przewodniczącymi składów orzekających w wielu przypadkach były osoby nie będące radnymi"77.

Wobec braku ustawowych wymogów posiadania wykształcenia prawniczego przez przewodniczącego kolegium i jego zastępcę funkcje te pełniły osoby dobierane z klucza partyjnego. Nawet udział przewodniczącego kole-

\footnotetext{
${ }^{75}$ H. Chmielewski, op. cit., s. 5 - 6.
}

${ }^{76}$ Sprawozdanie Ministerstwa Kontroli Państwowej z kontroli orzecznictwa karno-administracyjnego przeprowadzonej w 1956 r. woj. kieleckim, warszawskim, wrocławskim, IPN BU MSW II 6443 , s. 50

${ }^{77}$ Notatka informacyjna dla Kolegium Ministerstwa o przebiegu orzecznictwa karno-administracyjnego w 1955 r., IPN BU MSW II 6443, s. 33. 
gium lub jego zastępcy w pracach składu orzekającego nie gwarantował fachowego przewodnictwa rozprawie przez osobę zorientowaną w skomplikowanej materii prawa karno-administracyjnego. Skutkiem tego była niedostateczna znajomość przepisów prawa przez pozbawionych fachowego przewodnictwa członków składów orzekających, która prowadziła do niewłaściwego kwalifikowania spraw i dowolności w wymierzaniu kar. Prowadziło to do tego rodzaju sytuacji, jakie miały miejsce w województwie wrocławskim, gdzie „kolegium odwoławcze przy prezydium WRN na 88 orzeczeń w sprawach pozaskupowych uchyliło 21 orzeczeń z powodu nieprzestrzegania właściwych przepisów prawnych przez kolegia szczebla powiatowego, a w 42 wypadkach stwierdzono w orzeczeniach brak podstawy prawnej do ukarania obwinionych". Z kolei dowolność w wymierzaniu kar prowadziła do orzekania kar niewspółmiernych do wagi popełnionego wykroczenia, o czym świadczyć mogą orzeczenia kolegiów wymierzające grzywny za palenie papierosów w sklepie spożywczym lub pozostawienie bez opieki konia na ulicy w tej samej wysokości jak za społecznie niebezpieczne wykroczenia alkoholowo-chuligańskie ${ }^{78}$.

Krytycznie oceniono także sam tryb przeprowadzana wyborów, gdyż wprawdzie członkowie kolegiów byli wybierani na sesjach rady narodowej, lecz ,typowanie ich przez organizacje społeczne i zakłady pracy miało charakter mechaniczny". Radni powoływali na członków kolegiów zupełnie nieznane im osoby, które za wyniki swojej pracy nie odpowiadały ani przed radą narodowa, ani przed typująca ich organizacją społeczną. Brak skonkretyzowanej odpowiedzialności za sposób wykonywania funkcji członka kolegium prowadził do lekceważenia obowiązków przez znaczną część osób wchodzących w skład kolegiów. Jako przykład podawano kolegia szczebla wojewódzkiego w Warszawie i Kielcach, gdzie „przeszło 50\% członków nie brało nigdy udziału w posiedzeniach". Jeszcze gorzej przedstawiała się sytuacja w kolegium przy prezydium Wojewódzkiej Rady Narodowej we Wrocławiu, gdyż „na 196 członków tylko 18 brało udział w rozprawach”79.

Sformułowane przez Ministerstwo Kontroli Państwowej wnioski wskazywały na potrzebę zmian ustawy z 15 grudnia $1951 \mathrm{r}$. w kierunku zagwarantowania właściwego doboru członków kolegiów pod względem ich przygotowania fachowego oraz bliższego powiązania kolegiów z radami narodowymi. Postulowano typowanie kandydatów na członków kolegiów podczas zebrań załóg w zakładach pracy, co rodziłoby odpowiedzialność o charakterze moralnym przed kolegami z pracy „za aktywną i właściwą działalność kolegium”. Rady narodowe nie powinny ograniczać się do zatwierdzenia składu kolegium, lecz poprzedzać wybory dyskusją nad poszczególnymi kandydatami i w razie

${ }^{78}$ Sprawozdanie Ministerstwa Kontroli Państwowej z kontroli orzecznictwa karno-administracyjnego przeprowadzonej w $1956 \mathrm{r}$. w woj. kieleckim, warszawskim, wrocławskim, IPN BU MSW II 6443, s. 50-52.

${ }^{79}$ Ibidem, s. 51. 
wątpliwości wycofywać kandydatury nie cieszące się zaufaniem wszystkich radnych. Zainteresowanie rad narodowych orzecznictwem karno-administracyjnym powinno mieć miejsce nie tylko podczas wyborów składu kolegium, lecz towarzyszyć kolegium przez cały okres jego kadencji, gdyż jak stwierdzono „rady narodowe winny stale otaczać kolegia opieką, czuwać nad prawidłowością ich pracy i wpływać na poprawę stylu ich pracy”. Celem podniesienia poziomu pracy kolegiów Ministerstwo Kontroli Państwowej postulowało powoływanie przez rady narodowe stałych składów orzekających w poszczególnych dziedzinach, co ,pozwoliłoby członkom kolegiów nie tylko na lepsze zapoznanie się $\mathrm{z}$ obowiązującymi w tej dziedzinie przepisami, lecz orientowałoby członków tych kolegiów co do ogólnej liczby wykroczeń oraz przedsiębrania środków koniecznych do zwalczania przejawów łamania przepisów w danym zakresie". Jako szczególnie ważne dla podniesienia poziomu funkcjonowania kolegiów uznano ,zapewnienie kolegiom, a nawet poszczególnym składom orzekającym fachowego przewodnictwa". Przewodniczący kolegium powinien posiadać wykształcenia prawnicze oraz znajomość prawa karno-administracyjnego, dzięki czemu mógłby czuwać „nad przestrzeganiem praworządności przy orzekaniu i wykonywaniu orzeczonych kar”. Natomiast składami orzekającymi rozpatrującymi sprawy o określone wykroczenia powinni kierować specjaliści z poszczególnych dziedzin ${ }^{80}$, co miało spowodować że „sprawa będzie szczególnie wnikliwie rozpatrzona” oraz pozwalało „zrezygnować z wzywania biegłych z danej dziedziny, którym przecież płaci się za udział w posiedzeniach" ${ }^{\prime \prime}$.

IV. Problem kolegiów gromadzkich. Kolejnym problemem wynikłym na gruncie praktycznej realizacji ustawy z 15 grudnia 1951 r., który w gorącym okresie przemian 1956 r. stał się przedmiotem ożywionej dyskusji, była zasadność dalszego utrzymywania kolegiów szczebla gromadzkiego. Powołane do życia na początku $1955 \mathrm{r}$. kolegia gromadzkie w praktyce nie przejawiały szerszej aktywności. Niektóre z nich w ogóle nie przystapiły do orzekania, a ich członkowie nie wykazywali żadnego zainteresowania pracą w kolegium. Przyczyną takiego stanu rzeczy była zbyt duża liczba kolegiów gromadzkich w stosunku do możliwości kadrowych i organizacyjnych aparatu karno-administracyjnego prezydiów powiatowych rad narodowych. W miejsce dotychczasowych kolegiów szczebla gminnego utworzono 2-3 kolegia gromadzkie, co przy dużej licznie gromad w powiecie (od 40 do 60) utrudniało sprawowanie regularnej opieki i instruktażu ze strony powiatowego aparatu karno-administracyjnego. Wprawdzie w 1955 r. dwukrotnie przeprowadzano akcję szkolenia członków

${ }^{80}$ Ibidem.

${ }^{81}$ Jako przykład podano powierzenie spraw o wykroczenia przeciwko przepisom ruchu drogowego zasiadającym w kolegium „działaczom sportu motorowego lub kierowcom samochodowym”. J. Chełmiński, J. Malinowski, op. cit., s. 67. 
tych kolegiów, lecz wobec braków kadrowych aparatu karno-administracyjnego kolegia gromadzkie otrzymywały „,niedostateczną pomoc i nadzór ze szczebla powiatowego". Zdaniem Biura Nadzoru w części województw ,instruktorzy wydziałów organizacyjnych nie wykonali swych obowiązków" w zakresie szkolenia członków kolegiów gromadzkich, skutkiem czego kolegia te „w zasadzie nie przejawiły żywszej aktywności" 82 . Poważnym problemem był właściwy dobór członków kolegiów pod względem przygotowania fachowego, gdyż trudno było w gromadach i osiedlach znaleźć wystarczającą liczbę osób posiadającą, ,znajomość prawa niezbędną do orzekania w sprawach o wykroczenia". Niechętne podejście do pracy w kolegiach gromadzkich wykazywali ich członkowie, którzy byli powiązani z miejscową ludnością węzłami rodzinnymi lub „kumoterskimi” lub też z obawy przed pogorszeniem stosunków z sąsiadami unikali wymierzania $\operatorname{kar}^{83}$. Ze względu na powszechną znajomość ludzi w obrębie gromady nie wchodziło w grę stosowanie przepisów o wyłączeniu się członka kolegium od orzekania w sprawie, gdyż wtedy nie miałby kto rozpatrzeć sprawy ${ }^{84}$. Wybrani na członków kolegiów gromadzkich rolnicy indywidualni unikali udziału w posiedzeniach kolegiów, tłumacząc się obowiązkami związanymi z praca na roli, wskutek czego „w gromadach trudno jest zebrać skład orzekający". W sprawozdaniu z przebiegu orzecznictwa karno-administracyjnego na terenie województwa rzeszowskiego w II kwartale 1956 r. samokrytycznie przyznano, iż zamiast czynnika społecznego w kolegiach gromadzkich „orzekają często Przewodniczący Kolegium, jego zastępca i pracownik Prezydium, co jest sprzeczne z duchem ustawy o orzecznictwie k.a." $" 85$

Nie bez wpływu na poziom funkcjonowania kolegiów gromadzkich pozostawał brak wyspecjalizowanego aparatu karno-administracyjnego, wskutek czego obsługę kolegiów powierzono pracownikom referatów ogólnoadministracyjnych. Zarówno członkowie prezydiów, jak też ich pracownicy nie posiadali z reguły wiedzy z zakresu prawa karno-administracyjnego, co prowadziło do sytuacji, w której „sprawy nie są na bieżąco rejestrowane, niewłaściwie rozpatrywane oraz niekonsekwentnie wykonywane". Opinia ta została sformułowana w sprawozdaniu z przebiegu orzecznictwa karno-administracyjnego na terenie województwa bydgoskiego w 1955 r., zawierającym stwierdzenie, iż "najtrudniejszym problemem w pracy orzecznictwa karno-administracyjnego"

${ }^{82}$ Uwaga ta dotyczyła zwłaszcza województw: warszawskiego, opolskiego, rzeszowskiego, krakowskiego i olsztyńskiego. Notatka informacyjna dla Kolegium Ministerstwa o przebiegu orzecznictwa karno-administracyjnego w 1955 r., IPN BU MSW II 6443, s. 30.

${ }^{83}$ J. Jasiński, Młodszy brat sqdów, „Prawo i Życie” 1958, nr 9, s. 2.

${ }^{84}$ Notatka informacyjna dla Kolegium Ministerstwa o przebiegu orzecznictwa karno-administracyjnego w 1956 r., IPN BU MSW II 4, s. 287.

${ }^{85}$ Sprawozdanie Zarządu Spraw Wewnętrznych Prezydium Wojewódzkiej Rady Narodowej w Rzeszowie o orzecznictwie karno-administracyjnym za II kwartał 1956 r., IPN BU MSW I 526, s. 619 . 
są kolegia gromadzkie ${ }^{86}$. W sprawozdaniu jest mowa o panującym w części prezydiów bałaganie kompetencyjnym, wskutek czego „,członkowie Prezydium w poszczególnych GRN [...] nie wiedzą niejednokrotnie kto właściwie ma się zająć tymi sprawami [karno-administracyjnymi - przyp. autora], czy sekretarz, czy referent, który prowadzi sprawy meldunkowo-wojskowe”. Prowadziło to do zaniedbań w opracowywaniu wniosków o ukaranie i terminowym kierowaniu ich do rozpatrzenia przez kolegium, a w konsekwencji do przedawnienia znacznej części wniosków ${ }^{87}$. Stąd też organy MO zaprzestały kierowania zawiadomień do kolegiów gromadzkich, wnosząc wnioski o ukaranie nawet za drobne wykroczenia wprost do kolegiów powiatowych ${ }^{88}$. Statystyki obejmujące przebieg orzecznictwa karno-administracyjnego na wsi w latach 1954-1955 wskazują na wyraźny spadek liczby wniosków o ukaranie skierowanych do kolegiów gromadzkich w 1955 r. na tle danych obejmujących ostatni rok działalności kolegiów gminnych ${ }^{89}$. Pomimo znacznego wzrostu liczby kolegiów na najniższym szczeblu podziału terytorialnego kraju, liczba osób ukaranych przez kolegia funkcjonujące na wsi uległa zmniejszeniu o ponad jedną trzecią ${ }^{90}$. Jedynym pozytywnym zjawiskiem odnotowanym w statystykach była zmiana proporcji pomiędzy liczbą spraw rozstrzygniętych po przeprowadzeniu rozprawy i w drodze wydania nakazu karnego ${ }^{91}$, gdyż kolegia gromadzkie zdecydowanie preferowały zasadę kolegialności orzekania. Należy jednak zwrócić uwagę na fakt, iż w ostatnim roku funkcjonowania kolegia gminne szeroko stosowały tryb nakazowy celem niedopuszczenia do powstania zaległości w rozpatrywaniu spraw o wykroczenia ${ }^{92}$, dzięki czemu wię-

${ }^{86}$ Analiza z przebiegu orzecznictwa karno-administracyjnego za rok 1955 z terenu województwa bydgoskiego, IPN BU MSW II 625, s. 21.

${ }^{87}$ W II kwartale pozostawiono bez rozpatrzenia $27 \%$ wniosków o ukaranie. Notatka o przebiegu orzecznictwa karno-administracyjnego w II kwartale 1955 r. opracowana na podstawie materiałów z województw, IPN BU MSW II 522, s. 4

${ }^{88}$ Analiza z przebiegu orzecznictwa karno-administracyjnego za rok $1955 \mathrm{z}$ terenu województwa bydgoskiego, IPN BU MSW II 6625, s. 22-23.

${ }^{89} \mathrm{~W} 1954$ r. do kolegów gminnych wpłynęło 331520 zawiadomień, zaś nowo utworzone kolegia gromadzkie otrzymały do rozpatrzenia w 1955 r. 244394 sprawy. Orzecznictwo k-a na wsi (ruch spraw w b. kolegiach gminnych i kolegiach gromadzkich) w latach 1954-1955, IPN BU MSW I 11 + 2, s. 308 .

${ }^{90} \mathrm{~W}$ ostatnim roku działalności kolegia gminne ukarały 298133 osoby, zaś w 1955 r. kolegia gromadzkie wymierzyły kary wobec 191594 osób. Orzecznictwo k-a na wsi (ilość ukaranych w b. kolegiach gminnych i kolegiach gromadzkich w latach 1954-1955), IPN BU MSW I $11+2$, s. 307.

${ }^{91} \mathrm{~W} 1954$ r. kolegia gminne ukarały po przeprowadzeniu rozprawy 184665 osób, zaś w 113468 przypadkach rozstrzygnęły sprawę w drodze wydania nakazu karnego. Z kolei kolegia gromadzkie w pierwszym roku działalności ukarały po przeprowadzeniu rozprawy 146293 osoby i wydały jedynie 45301 nakazów karnych. Orzecznictwo k-a na wsi (ruch spraw w b. kolegiach gminnych i kolegiach gromadzkich) w latach 1954-1955, IPN BU MSW I $11+2$, s. 308.

${ }^{92}$ Sprawozdanie opisowe do wzoru MSW-2 z orzecznictwa karno-administracyjnego na terenie województwa białostockiego za I kwartał 1955 r., IPN BU MSW I 526, s. 320. 
kszość kolegiów gromadzkich mogła rozpocząć pracę w drugim kwartale 1955 r. z czystym kontem.

Utworzeniu kolegiów gromadzkich towarzyszyło zatem przesunięcie ciężaru orzekania się na kolegia powiatowe, które były „bardzo przeciążone rozpatrywaniem zawiadomień", podczas gdy kolegia gromadzkie otrzymywały przeciętnie do rozpatrzenia 2-3 wnioski w ciągu miesiąca. Przykładowo w województwa białostockim w I kwartale 1956 r. do kolegiów powiatowych kierowano przeciętnie 104 wnioski, podczas gdy na szczeblu gromadzkim kolegia rozpatrywały 2 sprawy miesięcznie ${ }^{93}$. Celem ożywienia kolegiów gromadzkich w pierwszej połowie 1956 r. prezydia wojewódzkich i powiatowych rad narodowych zaczęły kierować część spraw, które wpłynęły do kolegiów powiatowych, do rozpatrzenia przez kolegia gromadzkie. Działania te nie przyniosły większych rezultatów, gdyż spora część kolegiów gromadzkich wskutek bałaganu organizacyjnego nie prowadziła dokumentacji spraw karno-administracyjnych i nie nadawała dalszego biegu otrzymanym wnioskom. $Z$ danych Biura Nadzoru wynika, iż przeciętnie w skali kraju jedno kolegium gromadzkie w 1956 r. wydało 19 orzeczeń, podczas gdy kolegium powiatowe rozpatrzyło 1400 spraw. Utworzenie kolegiów gromadzkich nie zdołało odciążyć kolegiów powiatowych od rozpatrywania drobnych spraw o wykroczenia, zdecydowanie lepiej pod tym względem wypadły zlikwidowane kolegia szczebla gminnego, gdyż wydawały one około 100 orzeczeń w skali roku.

Konsekwencją słabej aktywności kolegiów na najniższym szczeblu podziału administracyjnego kraju był niski poziom orzecznictwa karno-administracyjnego w gromadach, gdyż członkowie składów orzekających nie mieli możliwości zdobycia choćby minimalnego doświadczenia w pracy. Kolegia nie mogły prowadzić konsekwentnej polityki karno-administracyjnej, a nieliczne orzeczenia były wydawane często z rażącym naruszeniem przepisów prawa materialnego i podstawowych zasad proceduralnych ${ }^{94}$. Prowadziło to do takich absurdów jak ,ukaranie odrobkiem chłopa, który skradł koniczynę ze spółdzielczego pola", czy też wydanie przez kolegium gromadzkie decyzji w sprawach o podział spadku ${ }^{95}$. Stąd, oceniając w drugiej połowie 1956 r. pracę kolegiów gromadzkich stwierdzono „liczne [...] wypadki wydawania bezprawnych orzeczeń, naruszających zasady praworządności ludowej oraz wywołujących zrozumiałe rozgoryczenie wśród obywateli" ${ }^{96}$. O niskim poziomie funkcjonowania orzecznictwa karno-administracyjnego na szczeblu gromadz-

${ }^{93}$ D. Egierska, Orzecznictwo karno-administracyjne wkracza na właściwą drogę, „PdKO” 1956, nr 4, s. 11.

${ }^{94}$ Uzasadnienie projektu nowelizacji ustawy z dnia 15 grudnia 1951 r. o orzecznictwie karno-administracyjnym, IPN BU MSW II 6439, s. 406.

${ }^{95}$ Notatka informacyjna dla Kolegium Ministerstwa o przebiegu orzecznictwa karno-administracyjnego w 1956 r., IPN BU MSW II IPN 4, s. 288.

${ }^{96} \mathrm{Z}$ doświadczeń kolegiów orzekających w woj. łódzkim, „PdKO” 1956, nr 5, s. 8. 
kim świadczy również odnotowana w II połowie 1956 r. praktyka organów MO, które zamiast do kolegiów powiatowych ,zaczęły kierować sprawy do Kolegiów gromadzkich, gdyż te nie kwestionują wagi i sposobu wypełniania zawiadomień" $"$ 97.

Zdaniem Biura Nadzoru dwuletni okres działalności kolegiów gromadzkich wykazał, iż nie zdały one egzaminu. Poważne trudności w pobudzeniu części tych kolegiów do aktywnej działalności oraz „,praktyczna niemożność zabezpieczenia przestrzegania przepisów prawa przez kolegia gromadzkie" miały przemawiać za rezygnacją z ich dalszego utrzymywania na rzecz przekazania całości orzecznictwa karno-administracyjnego kolegiom powiatowym. Dokonana przez Biuro Nadzoru w 1956 r. analiza działalności kolegiów powiatowych miała wykazać, że „są one w stanie przejąć w pełni sprawy napływające do kolegiów gromadzkich i nadać im właściwy bieg, tym bardziej że w ostatnim okresie kolegia powiatowe szeroko stosują sesje wyjazdowe do niektórych wsi" ${ }^{98}$. Stanowisko Biura Nadzoru popierały prezydia wojewódzkich i powiatowych rad narodowych, podkreślając brak szerszej aktywności orzecznictwa karno-administracyjnego na szczeblu gromadzkim ${ }^{99}$.

Wnioski. Wprowadzająca kolegialny tryb rozpatrywania spraw karno-administracyjnych ustawa z 15 grudnia 1951 r. miała stanowić wyraz „dużego postępu w organizacji organów do spraw wykroczeń, postępu na miarę dokonywanych w tym czasie reform społecznych i ustrojowych". Na praktykę funkcjonowania socjalistycznego modelu orzecznictwa karno-administracyjnego decydujący wpływ wywarło zbyt silne powiązanie instytucjonalne i personalne kolegiów z prezydiami rad narodowych ${ }^{100}$. Uzależnienie kolegiów od prezydiów rad narodowych wywarło ujemny wpływ na funkcjonowanie orzecznictwa karno-administracyjnego w okresie stalinowskim, gdyż prezydia nie wykazywały troski „o poziom orzecznictwa karno-administracyjnego, o prace kolegiów orzekających" ${ }^{\prime 101}$. Świadczy o tym chociażby formalistyczne podejście do przeprowadzania wyborów członków kolegiów, prowadzące do wykonywania orzecznictwa karno-administracyjnego przez osoby nieposiadające ku temu fachowych kwalifikacji.

Nic zatem dziwnego, że wskazując w 1955 r. na występowanie ,poważnych braków i wypaczeń w polityce k.a.”, Biuro Nadzoru za jedną z przyczyn

\footnotetext{
${ }^{97}$ Sprawozdanie Zarządu Spraw Wewnętrznych Prezydium Wojewódzkiej Rady Narodowej w Rzeszowie o orzecznictwie karno-administracyjnym za II kwartał 1956 r., IPN BU MSW I 526, s. 619.

${ }^{98}$ Notatka informacyjna dla Kolegium Ministerstwa o przebiegu orzecznictwa karno-administracyjnego w 1956 r., IPN BU MSW 4, s. 288.

${ }^{99}$ Uzasadnienie działu III projektu „Prawa Karno-Administracyjnego”, IPN BU MSW II 4, s. 241.

${ }^{100}$ K. Siarkiewicz, op. cit., s. 37.

${ }^{101}$ E. Dornfest, Przed wyborami do kolegiów..., s. 31
} 
takiego stanu rzeczy uznało „niedocenianie orzecznictwa k.a. przez prezydia rad narodowych i związaną z tym słabą pomoc dla kolegiów orzekających i aparatu k.a."102 Było to szczególnie widoczne na najniższym szczeblu podziału terytorialnego kraju, gdzie funkcjonujące od 1954 r. kolegia gromadzkie były pozbawione fachowej opieki i pomocy ze strony prezydiów powiatowych rad narodowych. Bez pomocy ze strony powiatu prezydia gromadzkich rad narodowych nie były w stanie zapewnić kolegiom należytych warunków do prawidłowego orzekania, stąd próba zbliżenia orzecznictwa karno-administracyjnego do obywateli poprzez utworzenie kolegium w każdej gromadzie i osiedlu zakończyła się niepowodzeniem. Liczne przypadki rażących naruszeń prawa w orzecznictwie kolegiów gromadzkich, spowodowane brakiem fachowych kwalifikacji i doświadczenia w pracy administracyjnej członków składów orzekających w pełni uzasadniały wysuwane na fali wydarzeń 1956 r. postulaty likwidacji orzecznictwa karno-administracyjnego na najniższym szczeblu podziału administracyjnego kraju.

Rok 1956 przynosi wzrost zainteresowania prezydiów rad narodowych orzecznictwem karno-administracyjnym, gdyż prawie wszystkie wojewódzkie rady narodowe miały dokonać na sesjach lub posiedzeniach prezydium oceny pracy kolegiów, „wysuwając wiele postulatów zmierzających do podniesienia poziomu tej pracy, niejednokrotnie w postaci konkretnych wniosków zmierzających do znowelizowania ustawy z 15 XII 1951 r." 103 . Krytykując regulacje dotyczacych trybu powoływania i organizacji pracy kolegiów, opowiadano się za wprowadzeniem rozwiązań gwarantujących właściwy dobór członków kolegiów pod względem ich przygotowania fachowego, w tym zapewnienia kolegiom, a nawet poszczególnym składom orzekającym przewodnictwa osoby posiadającej wykształcenie prawnicze.

Opinie sformułowane na kanwie negatywnej oceny funkcjonowania kolegiów w okresie stalinowskim posłużyły za podstawę reformy orzecznictwa karno-administracyjnego przeprowadzonej przez władze gomułkowskie w grudniu 1958 r. ${ }^{104}$ Wprawdzie reforma ta nie zmieniła ogólnej koncepcji ustrojowej organów orzekających w sprawach o wykroczenia, lecz dokonała istotnej zmiany w strukturze kolegiów, znosząc obligatoryjność ich tworzenia na szczeblu gromadzkim. Kosztem zmniejszenia liczby kolegiów postawiono na podniesienie jakości orzecznictwa poprzez dobór ludzi o odpowiednich kwalifikacjach na stanowiska przewodniczących kolegiów, ich zastępców oraz przewodniczących składów orzekających. W stosunku do przewodniczących kolegiów i ich zastępców wprowadzono wymóg posiadania ukończonych stu-

${ }^{102}$ Notatka w sprawie działalności Biura Nadzoru nad Orzecznictwem Karno-Administracyjnym, IPN BU MSW II 524, s. 14

${ }^{103}$ H. Chmielewski, op. cit., s. 3.

${ }^{104}$ Ustawą z dnia 2 grudnia 1958 r. o zmianie ustawy o orzecznictwie karno-administracyjnym (Dz. U. nr 77, poz. 396). 
diów prawniczych, zaś na przewodniczących składów orzekających w pierwszej kolejności miały być powoływane osoby z wykształceniem prawniczym lub osoby posiadające przynajmniej znajomość stosowania przepisów prawa administracyjnego i karno-administracyjnego. Celem umożliwienia praktycznej realizacji tego wymogu zrezygnowano $\mathrm{z}$ obligatoryjnego wyboru na przewodniczącego kolegium członka prezydium danej rady narodowej i monopolu radnych na przewodniczenie składowi orzekającemu ${ }^{105}$.

Rozwiązania wprowadzone w grudniu 1958 r. w znacznym stopniu przyczyniły się do wyeliminowania występujących w okresie stalinowskim braków w organizacji kolegiów i poziomie przygotowania fachowego ich członków. Dlatego też zostały uwzględnione w stanowiącej część składową kodyfikacji prawa karno-administracyjnego ustawie z 20 maja 1971 r. o ustroju kolegiów do spraw wykroczeń ${ }^{106}$.

THE DEVELOPMENT OF THE REGIME OF THE ADJUDICATING BOARDS IN THE POLISH PEOPLE'S REPUBLIC BETWEEN 1952 AND 1956

In December 1951, a collegiate model of adjudicating on petty offences was introduced in Poland. The adjudicating boards were established at the local organs of state administration and included a member of the public sitting in them. Those organs drew lists of candidates for members of the adjudicating boards, who were appointed by work places (factories, plants, etc.) and social organisations. The lists were mechanically approved by national councils. It was only in 1955 when candidates were appointed based on their relevant skills and background. However, in very small units of administration (gromada), members of the adjudicating boards lacked basic administrative experience and often committed gross violations of law. Consequently, at the turn of 1956, the common opinion demanded liquidation of the penal-administrative adjudication power of adjudicating boards in gromadas.

${ }^{105}$ Uzasadnienie projektu nowelizacji ustawy z dnia 15 grudnia 1951 r. o orzecznictwie karno-administracyjnym, IPN BU MSW II 6439, s. 407-408.

${ }^{106}$ Dz. U. nr 12, poz. 118. 


\title{
CREATION DU RÉGIME DES COLLÈGES STATUANT \\ DE LA RÉPUBLIQUE POPULAIRE DE POLOGNE (1952-1956)
}

\author{
$\mathrm{R}$ é s u m é
}

En décembre 1951, la Pologne met en place un modèle collégial permettant de statuer sur les affaires de contravention. Les collèges statuant avec la participation d'un élément social sont à l'époque implantés près des organes de l'administration publique de proximité. Ces derniers établissaient les listes des candidats - membres potentiels des collèges, les candidats ayant été désignés par des entreprises et organisations sociales. L'élection des membres consistait en validation mécanique des listes par les conseils nationaux. Ce n'est qu'à partir de 1955 que les listes des candidats commencent à être établies avec la prise en compte de la préparation professionnelle du candidat à l'exercice de ces fonctions. Cette même année par ailleurs sont créés des collèges de communes sur des territoires moins importants. Leurs membres n'ayant pas acquis d'expérience professionnelle dans l'administration, des violations évidentes de la loi se produisent. Par conséquent, durant 1956, une année de tournant, la liquidation de jurisprudence pénale et administrative au sein des communes est généralement revendiquée. 